\title{
Coprophagy and coprorhexy in the copepods Acartia tonsa and Temora longicornis: clearance rates and feeding behaviour
}

\author{
Louise K. Poulsen*, Thomas Kiørboe \\ Department of Marine Ecology and Aquaculture, Danish Institute for Fisheries Research, Kavalergården 6, \\ 2920 Charlottenlund, Denmark
}

\begin{abstract}
Decades of sediment trap studies have revealed that zooplankton fecal pellets constitute a much smaller fraction of the sedimentary flux than expected from the abundance of copepods and their anticipated production rates of fecal pellets. The explanation for this is thought to be coprophagy (ingestion) of fecal pellets by copepods. We examined fecal pellet clearance rate of Acartia tonsa and Temora longicornis and feeding behaviour of $A$. tonsa. Pellet clearance rates in A. tonsa and T. longicornis females were similar but low on their own pellets (11 to $22 \mathrm{ml}$ female ${ }^{-1} \mathrm{~d}^{-1}$ ). Our own data together with observations compiled from the literature revealed that copepod fecal pellet clearance rates decrease with increasing relative pellet size and that all species can be described by a common relationship. In $A$. tonsa, the presence of alternative phytoplankton food increased pellet clearance rate. Direct observations revealed that this was accomplished through the modulating effect of phytoplankton on the feeding behaviour. In the absence of phytoplankton, $A$. tonsa is nonmotile but perceives sinking fecal pellets at distance. However, only a small fraction of the pellets that came within detection distance elicited an attack. In the presence of phytoplankton food, A. tonsa switched to suspension feeding, and all fecal pellets entrained in the feeding current were encountered. Independent of the feeding mode, fecal pellets were mainly degraded by fragmentation during rejection and only a small fraction was actually ingested (5\%). The main impact of $A$. tonsa on the vertical flux of fecal pellets is therefore through coprorhexy (fragmentation) turning fecal pellets into smaller, slower-sinking particles.
\end{abstract}

KEY WORDS: Coprorhexy $\cdot$ Coprophagy $\cdot$ Acartia tonsa $\cdot$ Temora longicornis $\cdot$ Fecal pellet clearance rate $\cdot$ Feeding mode $\cdot$ Behaviour

\section{INTRODUCTION}

Numerous field studies ( $>500$ ) using sediment traps have revealed that zooplankton fecal pellets often constitute a minor portion of the sedimentary flux, much less than what would be expected from the zooplankton abundances and expected fecal pellet production rates (González \& Smetacek 1994, Turner 2002). A reduced vertical flux is often attributed to recycling and repackaging of the fecal pellets by coprophagous (ingestion of pellets) copepods (Smetacek 1980, Bathmann et al. 1987, González \& Smetacek 1994, González et al. 1994a, Lane et al. 1994, Urban-Rich et al. 1999). Also, coprorhexy (fragmentation of pellets) and coprochaly (loosening of pellets) may increase the residence time of fecal material in the water column (Lampitt et al. 1990, Noji et al. 1991) and make it subject to enhanced microbial degradation (Turner 2002), thus accelerating recycling of fecal pellet material in the water column.

The importance of copepods for the degradation of fecal pellets is, however, poorly investigated. There are some reports with evidence of coprorhexy, coprochaly and coprophagy, and a few estimates of actual pellet grazing rates (Paffenhöfer \& Strickland 1970, Paffenhöfer \& Knowles 1979, Paffenhöfer \& Van 
Sant 1985, Ayukai \& Nishizawa 1986, Lampitt et al. 1990, González et al. 1994a,b). The reported grazing rates are, however, highly variable. Coprophagous and coprorhexious behaviour is most likely influenced by several factors including the species composition of the copepod community, which determines pellet size and sinking rate, and the food source, which influences pellet compaction (Hansen et al. 1996), sinking rate (Feinberg \& Dam 1998), nutritional value and, hence, susceptibility to pellet grazers. Also, the presence of alternative phytoplankton food may have an effect on pellet grazing, intuitively by making fecal pellets a less attractive food source, since some part of the ingested plankton is assimilated during digestion (Besiktepe \& Dam 2002) and because the larger pellet particles are more difficult to handle than the smaller phytoplankton cells (Berggreen et al. 1988). The feeding behaviour of a copepod also influences the rate at which pellets are encountered and eaten. Ambush feeding copepods, such as Oithona spp., are thought to perceive fecal pellets by the hydromechanical disturbance that they create while sinking through the water column (Svensen \& Kiørboe 2000) and large, rapidly sinking fecal pellets would be detectable at long distances and, therefore, potentially cleared at very high rates (Kiørboe \& Visser 1999). Ambush feeding copepods may, thus, be more important degraders of fecal pellets in the sea, and coprophagy would therefore be biased towards large pellets.

Here we investigated coprophagy in 2 common neritic copepod species, Acartia tonsa and Temora longicornis, through classical incubation experiments to estimate clearance rates, and through direct observations of the feeding behaviour of $A$. tonsa when graz- ing fecal pellets. We examined the influence of fecal pellet size, feeding mode, and the presence of an alternative food source on the clearance rates. A. tonsa was chosen for behavioural analysis because it, like some other copepods, may switch between ambush feeding, where the copepod is inactive while perceiving moving (or sinking) prey particles, and suspension feeding, where prey particles arriving in the feeding current are captured (Jonsson \& Tiselius 1990, Kiørboe et al. 1996).

\section{MATERIALS AND METHODS}

Cultures. Phytoplankton, Thalassiosira weissflogii (diatom) and Dunaliella tertiolecta (green alga), were maintained in exponential growth in $\mathrm{f} / 2$ medium (Guillard 1975). Copepods were grown in a laboratory culture at $18^{\circ} \mathrm{C}$ on a flagellate diet (Rhodomonas salina, cryptophyte) (Støttrup et al. 1986). Only females matured within 2 to $3 \mathrm{wk}$ were used in the experiments. Female copepods were acclimated to the experimental conditions for $24 \mathrm{~h}$ prior to experiments. All experiments were done at $17^{\circ} \mathrm{C}, 32 \%$ salinity, in darkness, and in Screw-cap bottles (320 or $620 \mathrm{ml}$ ) placed on a rotating wheel (1 rpm). All incubations were run in triplicate.

Grazing own fecal pellets. 'Own pellets' are defined as pellets produced by the incubated copepods during the incubation. The clearance rate of Acartia tonsa and Temora longicornis females on their own fecal pellets were estimated from incubations where females grazed either Thalassiosira weissflogii or Dunaliella tertiolecta (Expts 1 to 5, Table 1). The copepods were

Table 1. Experimental design. Copepod species, phytoplankton species and concentrations, sizes of offered fecal pellets as well as copepod concentration and incubation durations in the 9 grazing experiments. Varying female concentration is a Type 1 experimental design and varying incubation time is a Type 2 experimental design. ${ }^{*}$ The fecal pellets were not measured and therefore an equivalent spherical diameter (ESD) equal to Expt 2 was assumed. Pellet size is ESD (mean $\pm \mathrm{SD}$ ), $\mathrm{n}=20$ in 'grazing own pellets' experiments and $n=30$ in 'grazing other pellet' experiments

\begin{tabular}{|c|c|c|c|c|c|c|c|}
\hline $\begin{array}{l}\text { Expt } \\
\text { no. }\end{array}$ & $\begin{array}{l}\text { Expt } \\
\text { type }\end{array}$ & $\begin{array}{l}\text { Copepod } \\
\text { species }\end{array}$ & $\begin{array}{l}\text { Alternative } \\
\text { food source }\end{array}$ & $\begin{array}{l}\text { Initial algal conc. } \\
\left(10^{6} \text { cells }^{-1}\right)\end{array}$ & $\begin{array}{l}\text { Incubation } \\
\text { time (h) }\end{array}$ & $\begin{array}{l}\text { Female conc. } \\
\quad\left(\text { ind. } \mathrm{l}^{-1} \text { ) }\right.\end{array}$ & $\begin{array}{l}\text { Pellet size } \\
(\mathrm{ESD}, \mu \mathrm{m})\end{array}$ \\
\hline \multicolumn{8}{|c|}{ Grazing own pellets } \\
\hline 1 & 1 & Acartia tonsa & Thalassiosira weissflogii & 6 & 48 & 5 to 180 & $70^{*}$ \\
\hline 2 & 1 & A. tonsa & T. weissflogii & 10 & 48 & 5 to 180 & $70 \pm 5$ \\
\hline 3 & 2 & A. tonsa & T. weissflogii & 6 & 1 to 55 & 33 & $70^{*}$ \\
\hline 4 & 1 & A. tonsa & Dunaliella tertiolecta & 98 & 48 & 6 to 209 & $45 \pm 10$ \\
\hline 5 & 1 & Temora longicornis & T. weissflogii & 28 & 24 & 3 to 184 & $75 \pm 10$ \\
\hline \multicolumn{8}{|c|}{ Grazing other pellets } \\
\hline 6 & Varying & A. tonsa & T. weissflogii & 2 & 24 & 29 & $40 \pm 5$ \\
\hline 7 & pellet & A. tonsa & T. weissflogii & 13 & 48 & 77 & $130 \pm 25$ \\
\hline 8 & concen- & A. tonsa & - & - & 24 & 30 & $40 \pm 5$ \\
\hline 9 & tration & A. tonsa & - & - & 48 & 69 & $130 \pm 25$ \\
\hline
\end{tabular}


allowed to graze saturating concentrations of the alga to insure a constant production rate of fecal pellets. Incubation durations varied between 1 and $55 \mathrm{~h}$ (Table 1). After incubation, the fecal pellets were collected on a $15 \mu \mathrm{m}$ screen, preserved by acid Lugol's solution, and counted under a dissecting microscope. Pellet fragments of $A$. tonsa and T. longicornis were counted as a $1 / 2$ pellet. The average volume and equivalent spherical diameter (ESD) of the pellets were calculated from measurements of length and width of at least 30 fecal pellets in each experiment.

Feeding copepods simultaneously produce and graze fecal pellets. Assuming a constant specific fecal pellet production rate $\left(p\right.$, pellets female $\left.{ }^{-1} \mathrm{~h}^{-1}\right)$ and a constant specific clearance rate of pellets $\left(f, 1\right.$ female ${ }^{-1}$ $\left.\mathrm{h}^{-1}\right)$, the concentration of pellets $\left(C\right.$, pellets $\left.\mathrm{l}^{-1}\right)$ in the incubation bottles will vary with time according to

$$
\frac{\mathrm{d} C}{\mathrm{~d} t}=n p-n f C
$$

where $n$ is the concentration of females (females $\mathrm{l}^{-1}$ ) and $t$ is incubation time (h). With the boundary condition that the fecal pellet concentration at the start of the incubation is zero $\left(C_{0}=0\right)$, Eq. (1) integrates to:

$$
C(n, t)=\frac{p}{f}\left(1-\mathrm{e}^{-f t n}\right)
$$

Two types of incubations were conducted in order to estimate pellet production and pellet clearance rates: In Type 1 incubations, the incubation time was kept constant, and the concentration of animals was varied in simultaneous incubations (Table 1). Eq. (2) was then fitted to a plot of final concentration of fecal pellets as a function of animal concentration, and the parameters $(p, f)$ estimated. In Type 2 incubations, the concentration of animals was kept constant, but incubation time was varied in a series of simultaneous incubations (Table 1). Eq. (2) was fitted to a plot of final concentration of pellets as a function of incubation time, and the parameters estimated.

Grazing other fecal pellets. 'Other pellets' are defined as pellets which are added to the incubation bottle and not produced by Acartia tonsa females. Clearance and ingestion rates of adult $A$. tonsa were determined in experiments where females were offered fecal pellets that were clearly distinguishable as either larger or smaller than their own pellets (Expts 6 to 9, Table 1). Both fecal pellet sizes were offered with (Expts 6 and 7) or without (Expts 8 and 9) Thalassiosira weissflogii as an alternative food source (Table 1). The fecal pellets used were produced by $A$. tonsa CI to CIII copepodites (small pellets) and CV to CVI Calanus finmarchicus/helgolandicus (large pellets) feeding on Rhodomonas salina. After 18 to $20 \mathrm{~h}$ of feeding the pellets were separated from the copepods by filtration through a $180 \mu \mathrm{m}$ mesh, washed on a $30 \mu \mathrm{m}$ mesh to remove phytoplankton and then offered immediately to A. tonsa females. Separation and washing did not increase the fragmentation of the pellets. Incubations were run for $24 \mathrm{~h}$ when offering small fecal pellets and $48 \mathrm{~h}$ when offering large pellets. Incubation time was longer with large pellets to insure measurable ingestion and clearance rates. Ingestion and clearance rates of the fecal pellets were calculated according to the equations of Frost (1972). Fecal pellets were treated as above, with the exception that fragments of large Calanus pellets were counted as a $1 / 2$ or a $1 / 3$ pellet. In grazing experiments with 'other pellets' the pellets produced by the females during the experiments were not included in the clearance and ingestion rate estimates.

Grazing behaviour. The behaviour of the copepods was investigated by filming Acartia tonsa females feeding on fecal pellets both in the presence and absence of alternative food (Thalassiosira weissflogii). Fecal pellets for grazing were produced by $A$. tonsa, CI to CIII copepodites feeding on Rhodomonas salina. Filming was conducted in a cylindrical $(15 \mathrm{~cm}$ diameter, $10 \mathrm{~cm}$ depth) 'planktonkreisel' (Hamner 1990) with inflow and outflow connected to a water pump to create mixing. The flow rate was kept low to avoid disturbing the behaviour of the females, but high enough to slow down sedimentation of the fecal pellets in the chamber. Sedimented fecal pellets were resuspended by spraying water on the aquarium bottom every $\sim 15$ min during filming. The filming equipment consisted of a CCD video camera (Watec WAT-535EX) equipped with an $80 \mathrm{~mm}$ Macro zoom lens (Computar MLH-10X) and connected to a super-VHS video cassette recorder (Panasonic NV-FS200 HQ), a time-code generator (Panasonic WJ-810), and a video monitor. Infrared illumination was provided by an LED that was collimated through a condenser.

Thirty to fifty females were acclimated in filtered seawater overnight. The females and pellets were added to the aquarium $1 \mathrm{~h}$ prior to filming. After $\sim 1 \mathrm{~h}$ of filming Thalassiosira weissflogii was added to the aquarium $\left(6 \times 10^{6}\right.$ cells l $\left.^{-1}\right)$ and the females were again allowed to acclimate for $1 \mathrm{~h}$ before filming $(\sim 1 \mathrm{~h})$. Fecal pellets were counted before and after each filming and the average concentration was considered as the experimental concentration. Filming took place in a dark room at $17^{\circ} \mathrm{C}$. One female at a time was kept in focus and followed for at least $1 \mathrm{~min}$ if possible. Feeding behaviour in both the absence and presence of $T$. weissflogii as alternative food was filmed at 4 fecal pellet concentrations $\left(2,3,13\right.$ and 27 pellets $\mathrm{ml}^{-1}$ and 2,3 , 16 and 28 pellets $\mathrm{ml}^{-1}$, respectively). The behaviour of 3 randomly chosen females was recorded in each treatment. The video tapes were analysed frame-by-frame 


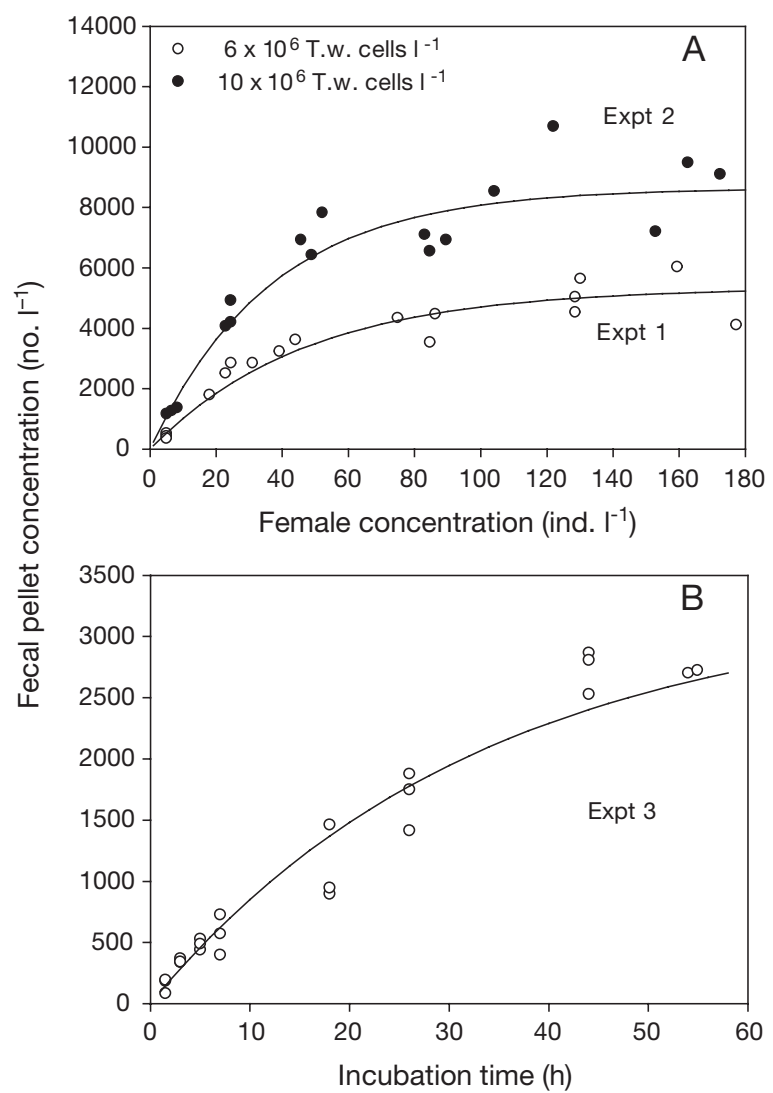

Fig. 1. Acartia tonsa. Grazing own fecal pellets in the presence of Thalassiosira weissflogii (T.w.). (A) Final fecal pellet concentration as a function of female concentration (Type 1 design, $t=48 \mathrm{~h}$ ) at 2 algal concentrations (Expt $1=6 \times 10^{6}$

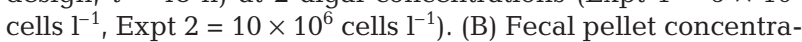
tion as a function of incubation time (Type 2 design, Expt 3, $n=33$ females $\mathrm{l}^{-1}$ ) at $6 \times 10^{6}$ cells $\mathrm{l}^{-1}$. The line is the fit of the model (Eq. 2). Please note different scales

and the fraction of time a female spend filtering, sinking or jumping was recorded for approximately $1 \mathrm{~min}$ per female. Periods when the females were close to the aquarium wall were excluded from the analysis. Furthermore, the number of rejected (R) and ingested (I) fecal pellets observed during 30 min of net filming with an animal in the view field were recorded for each treatment.

Statistical analysis. Estimates of fecal pellet clearance $(f)$ and production rates $(p)$ were obtained by fitting the logarithmic transformed model (Eq. 2) to the observations using the software ' $R$ ' (version 1.6.1). Maximum likelihood ratios were computed to test for differences between the estimated clearance rates. The filtration activity (\%), filtration duration, and sinking duration were tested for differences between treatments with ANCOVA (SPSS version 10.0), using the interactions between the treatment (absence/presence of alternative food) and average fecal pellet concentration (covariate).

\section{RESULTS}

\section{Clearance and ingestion of fecal pellets}

In the experiments where females of Acartia tonsa and Temora longicornis grazed their own pellets, fecal pellet concentration increased asymptotically with female concentration or incubation time towards a maximum, and the model (Eq. 2) provided good fits to the observations (Figs. 1 to 3 ). The estimates obtained from the model showed that $A$. tonsa females offered Thalassiosira weissflogii cleared their own fecal pellets at rates of 11 to $22 \mathrm{ml}$ female ${ }^{-1} \mathrm{~d}^{-1}$ (Table 2, Expts 1 to 3 ). The estimates based on Type 1 (varying animal concentration) and Type 2 (varying incubation time) experimental designs were not significantly different $(p=0.05$, Fig. 1). The concentration of $T$. weissflogii did not influence the rate at which $A$. tonsa cleared its own fecal pellets, since the clearance estimates were not significantly different $(\mathrm{p}<0.05)$ when the females grazed $6 \times 10^{6}$ or $10 \times 10^{6} \mathrm{~T}$. weissflogii cells $\mathrm{l}^{-1}$ (Fig. 1A). However, fecal pellets were produced at higher rates at the highest concentration of $T$. weissflogii (Table 2). The algal species offered along with the fecal pellets influenced the pellet feeding rate in $A$. tonsa since females grazing $T$. weissflogii cleared their own pellets at significantly higher rates than females grazing Dunaliella tertiolecta ( $\mathrm{p}<0.05$, Table 2$)$. This coincided with a low fecal pellet production rate of only 1 fecal pellet female ${ }^{-1} \mathrm{~h}^{-1}$ when feeding on $D$. tertiolecta. Temora longicornis females grazing $T$. weissflogii (Expt 5) cleared their own fecal pellets at a similar rate as $A$. tonsa females (Table 2).

Grazing of Acartia tonsa females on 'other fecal pellets' was dependent on the presence or absence

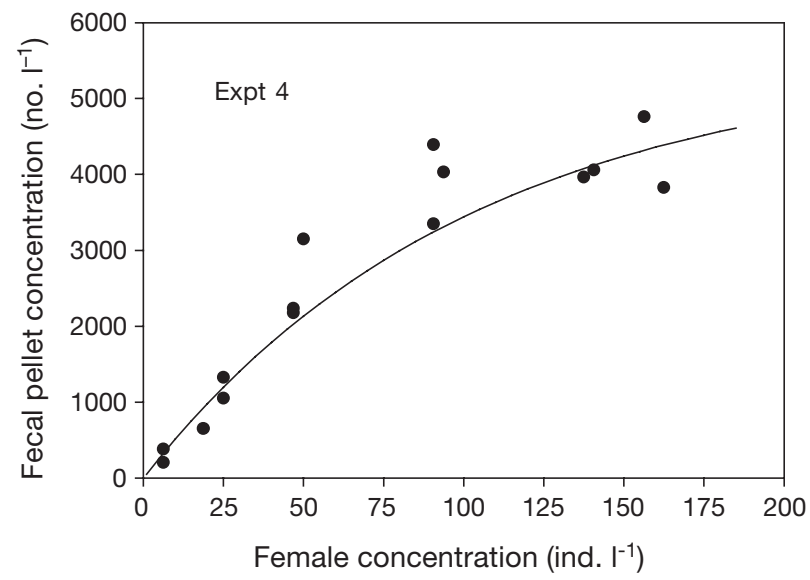

Fig. 2. Acartia tonsa. Grazing own fecal pellets in the presence of Dunaliella tertiolecta $\left(98 \times 10^{6}\right.$ cells l$^{-1}$, Expt 4). Final fecal pellet concentration as a function of female concentration (Type 1 design, $t=48 \mathrm{~h}$ ). The line is the fit of the model (Eq. 2). Expt = experiment number 


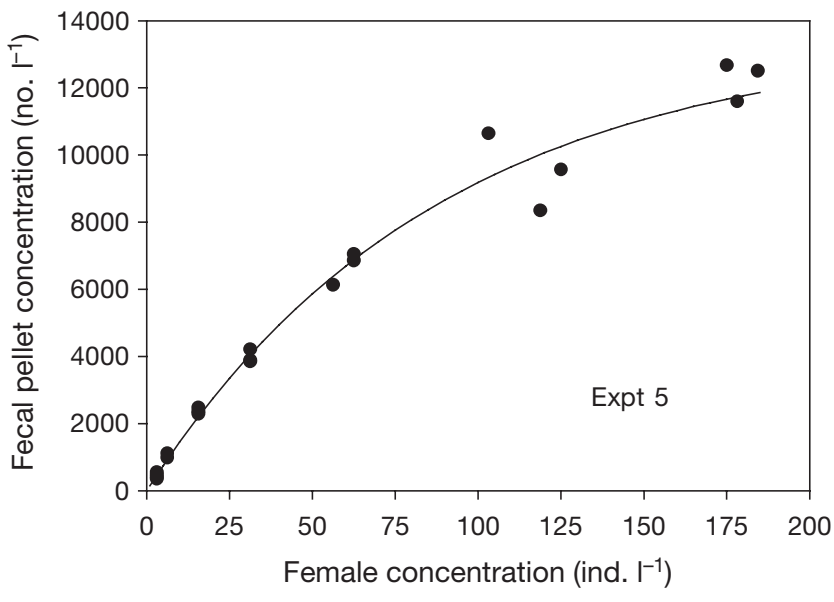

Fig. 3. Temora longicornis. Grazing own fecal pellets in the presence of Thalassiosira weissflogii $\left(28 \times 10^{6}\right.$ cells l $^{-1}$, Expt 5). Final fecal pellet concentration as a function of female concentration (Type 1 design, $t=24 \mathrm{~h}$ ). The line is the fit of the model (Eq. 2)

of alternative food (Thalassiosira weissflogii). The clearance of fecal pellets was near constant and independent of pellet concentration in the absence of phytoplankton, while the presence of phytoplankton induced a functional response in pellet clearance to the pellet concentration (Fig. 4A-D). This difference in the magnitude and functional response of pellet clearance was seen with both fecal pellet sizes (Fig. 4), although the feeding response was more pronounced when the females grazed small pellets (Fig. 4A,B). Thus, contrary to our expectations the fecal pellet clearance rates in $A$. tonsa females were higher in the presence of the alternative food than when pellets were offered as the sole food source (Fig. 4, Table 2).

The fecal pellet clearance and ingestion rate of Acartia tonsa females decreased with increasing pellet size. Thus, the females cleared small fecal pellets $(33 \mathrm{ml}$ female ${ }^{-1} \mathrm{~d}^{-1}$ ) at a higher rate than their own pellets (average $15 \mathrm{ml}$ female $^{-1} \mathrm{~d}^{-1}$ ) and the large Calanus
Table 3. Acartia tonsa. Maximum fecal pellet clearance (mean $\pm \mathrm{SD}$ ) as a function of varying pellet concentration of $A$. tonsa females offered small and large pellets in the absence and presence of Thalassiosira weissflogii as alternative phytoplankton food source. Experiments were done in triplicate

\begin{tabular}{|lccc|}
\hline $\begin{array}{l}\text { Expt } \\
\text { no. }\end{array}$ & $\begin{array}{c}\text { Pellet } \\
\text { size }\end{array}$ & $\begin{array}{c}\text { Alternative } \\
\text { food source }\end{array}$ & $\begin{array}{c}\text { Clearance rate }(f) \\
\left(\mathrm{ml} \mathrm{ind}^{-1} \mathrm{~d}^{-1}\right)\end{array}$ \\
\hline 6 & Small & Thalassiosira weissflogii & $33 \pm 5.3$ \\
7 & Large & T. weissflogii & $10 \pm 0.6$ \\
8 & Small & None & $12 \pm 1.5$ \\
9 & Large & None & $5 \pm 0.7$ \\
\hline
\end{tabular}

fecal pellets were cleared at the lowest rate $(10 \mathrm{ml}$ female $\mathrm{e}^{-1} \mathrm{~d}^{-1}$ ) (compare experiments with alternative food, Table 2, Fig. 4).

\section{Coprophagous feeding behaviour}

The feeding behaviour of Acartia tonsa females grazing fecal pellets in the presence or absence of alternative food (Thalassiosira weissflogii) was investigated in more detail using video recordings. The feeding behaviour of $A$. tonsa consists of feeding bouts interrupted by periods of sinking. During feeding bouts the animal generates a feeding current that pulls it forward while it collects prey particles arriving in the current ('suspension feeding'); during sinking events, moving prey particles may be perceived and attacked ('ambush feeding'). Ambush feeding females were observed to detect and attack sinking pellets at distances of up to 3 body lengths. The fraction of time employed in suspension feeding was significantly higher and the average duration of individual feeding bouts significantly longer in the presence of alternative phytoplankton food than when fecal pellets were offered alone at all fecal pellet concentrations $(\mathrm{p}<$ 0.005) (Fig. 5A,B). The average duration of sinking events was longer in the absence of phytoplankton only at the 2 highest pellet concentrations (Fig. 5C).

Fecal pellets offered as the sole food source thus induced a rather sluggish feeding behaviour dominated by ambush feeding. In this situation the females showed a very low suspension feeding activity $(<12 \%)$, short feeding bouts $(\sim 0.5 \mathrm{~s})$ and average sink durations $(\sim 1.7 \mathrm{~s})$, which lasted almost twice as long as when Thalassiosira weissflogii was present $(1.0 \mathrm{~s})$. The suspension feeding activity when $T$. weissflogii was offered as alternative food was much higher ( 78\%) (Fig. 5A). The 

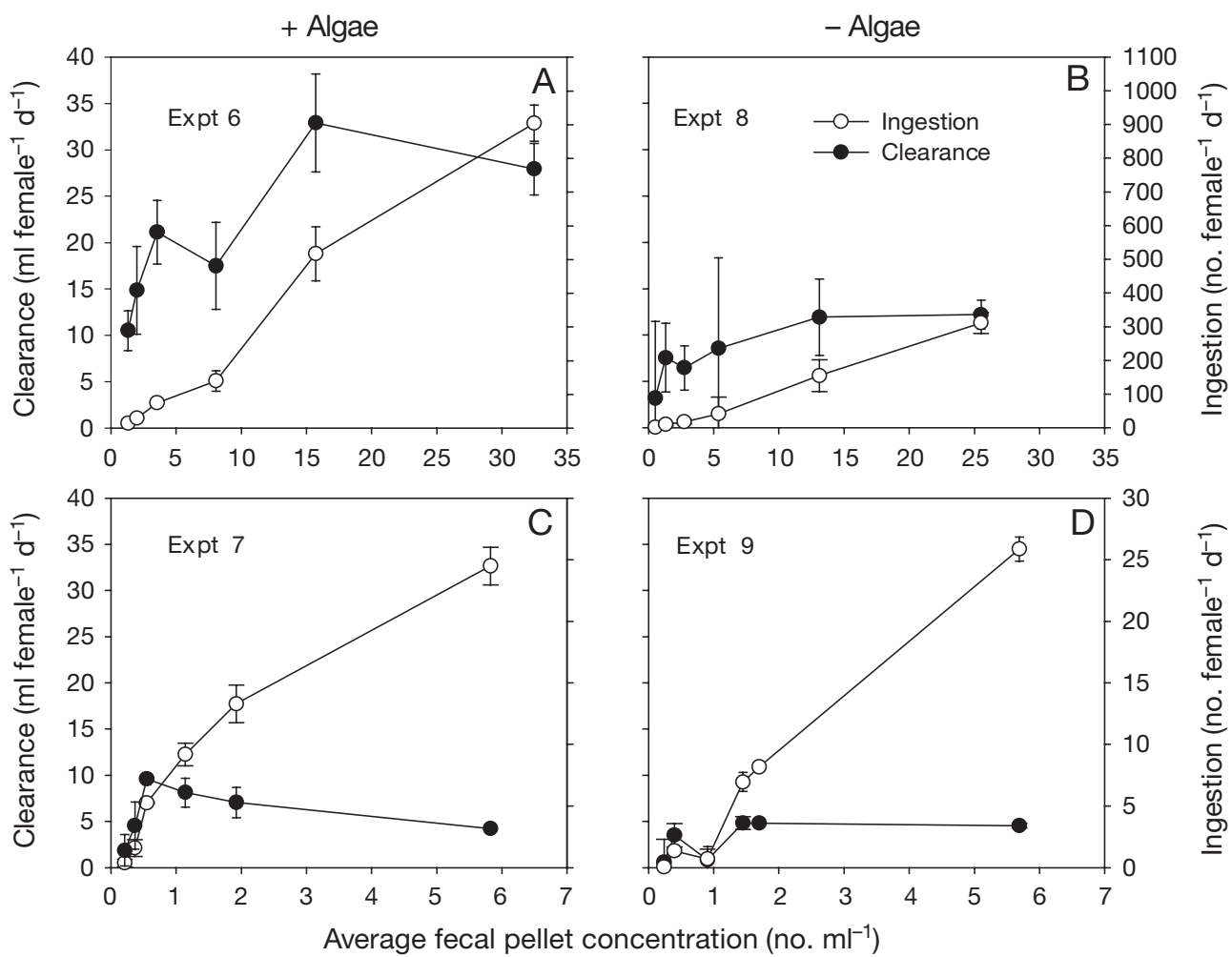

Fig. 4. Acartia tonsa. Average $( \pm \mathrm{SD})$ clearance and ingestion rates of $(\mathrm{A}, \mathrm{B})$ small and $(\mathrm{C}, \mathrm{D})$ large fecal pellets in the presence $(A, C)$ or absence $(B, D)$ of alternative food (the diatom Thalassiosira weissflogii). Average fecal pellet concentration, clearance and ingestion rates were calculated after Frost (1972)

increasing fecal pellet concentration did not induce an increase in filtration activity (ANCOVA covariate, $p=0.3$ to 0.4 ) or a switch in feeding mode in either feeding situation (Fig. 5A).

Actual capture and ingestion of a fecal pellet was observed only 4 times in 84 recorded copepod-pellet interactions (Table 4). This may even be an over estimation since a pellet rejected in the plane of the body into the view field may look like an ingestion. Only small fragments of fecal pellets were ingested whereas intact pellets or large fragments were rejected. In total, $\sim 95 \%$ of the fecal pellet particles (intact or fragments)

Table 4. Number of rejected (R) and ingested (I) fecal pellets observed during 30 min of net filming with an animal in the view field at various concentrations of fecal pellets and in the absence and presence of alternative phytoplankton food (Thalassiosira weissflogii)

\begin{tabular}{|lcccc|}
\hline $\begin{array}{l}\text { Fecal pellet } \\
\text { conc. } \\
\left(\mathrm{ml}^{-1}\right)\end{array}$ & \multicolumn{2}{c}{$\begin{array}{c}\text { Only pellets } \\
\text { (Ambush feeding) }\end{array}$} & \multicolumn{3}{c|}{$\begin{array}{c}\text { Pellets + algae } \\
\text { (Suspension feeding) } \\
\text { R }\end{array}$} & I & & I \\
\hline 2 & 1 & 0 & 6 & 2 \\
3 & 5 & 1 & 5 & 1 \\
15 & 5 & 0 & 29 & 0 \\
28 & 5 & 0 & 24 & 0 \\
\hline
\end{tabular}

caught in the feeding appendages were rejected. Fecal pellets were caught more often in the feeding appendages during suspension feeding at high fecal pellet concentrations than during ambush feeding (Table 4). Rejection of a captured pellet was observed in both feeding situations and feeding modes. A few rejected fecal pellets were observed to be visibly damaged or even cut in half after the encounter with the feeding appendages. This could only be observed for intact or large pellet fragments due to the high magnification needed to observe this.

\section{DISCUSSION}

\section{Estimation of clearance on own fecal pellets}

We used an indirect approach and a simple model to estimate the clearance rate of copepods on their own fecal pellets as it is impossible to estimate it directly. The model provided a good fit to the observations, and the estimates of the clearance rate of Acartia tonsa females on their own fecal pellets were intermediate of the estimates obtained in grazing experiments offering smaller and larger fecal pellets with Thalassiosira weissflogii as alternative food. The different approaches thus provide consistent estimates. 
Microbial degradation of fecal pellets during incubations may bias the estimate of the clearance rate toward higher values. However, the similarity of the clearance estimates when either copepod concentration or incubation time were varied (Type 1 and 2 experiments, respectively) suggests that this is a minor source of error, and that microbial degradation played a minor role in visibly removing the fecal pellets. Fecal pellets leak DOC rapidly after egestion, which is utilized primarily by non-attached bacteria (Jumars 1989, Urban-Rich 1999, Thor et al. 2003). Leakage of DOM,
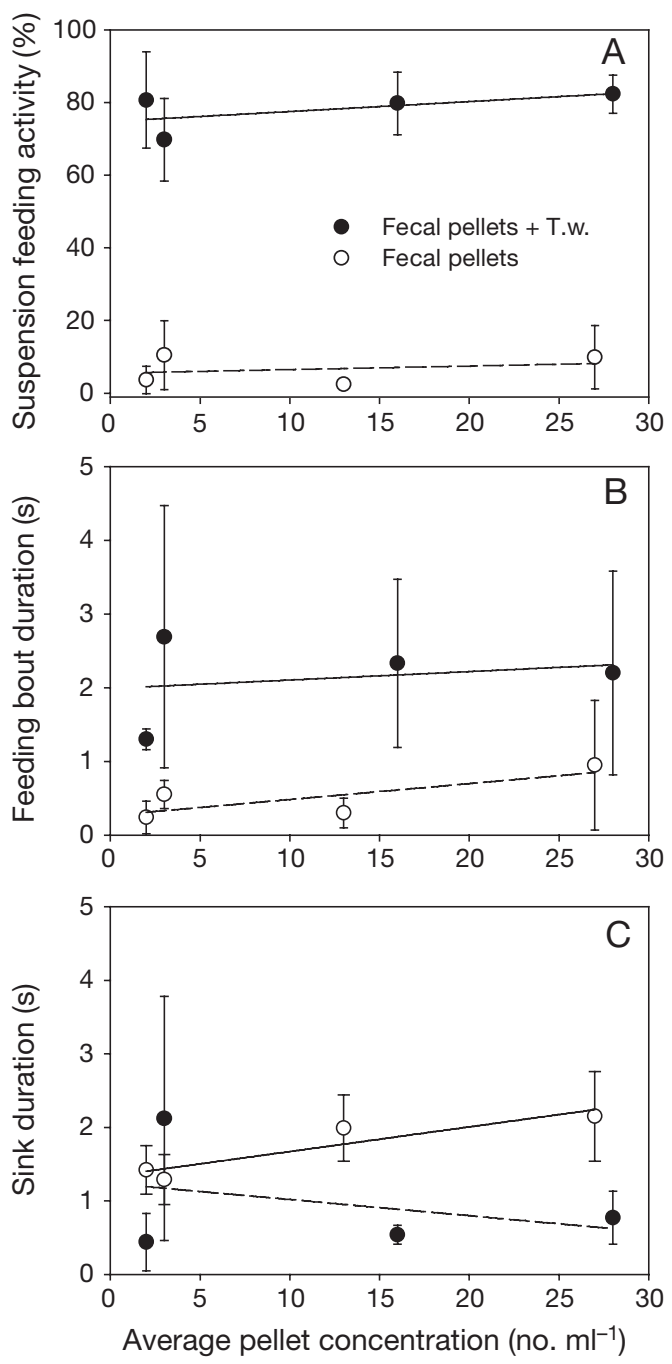

Fig. 5. Acartia tonsa. Female feeding behaviour as a function of fecal pellet concentration in the presence and absence of alternative food (Thalassiosira weissflogii). (A) Average suspension feeding activity as a percentage of total activity, (B) average feeding bout duration (s), and (C) average sink duration (s). Each point is the average \pm SD of the behaviour of 3 females $(n=3)$ during approximately 1 min recording time per female. The fraction of time a female spends filtering, sinking or jumping was recorded for approximately $1 \mathrm{~min}$ per female. $\mathrm{O}$ : fecal pellets $(\mathrm{ESD}=40 \mu \mathrm{m})$ offered alone; -: mixture of fecal pellets and the diatom T. weissflogii (T.w.) however, does not change the appearance of the pellets beyond recognition and they may still be counted as intact pellets or fragments. Furthermore, a low bacterial degradation of fecal pellets within the first 1 to $4 \mathrm{~d}$ of egestion has been observed in other studies (Jacobsen \& Azam 1984, Green et al. 1992).

There is a risk in Type 1 experiments that the highest animal concentration stresses the animals, depressing normal grazing behaviour. This was most likely not a serious problem since the clearance estimates in Type 1 experiments were not significantly different from the estimate obtained in the Type 2 experiments where the animal concentration was lower. Furthermore, the ingestion of the algae, which was monitored in the experiments, was high demonstrating that the grazing behaviour of the females was not depressed.

\section{Processes governing the clearance of fecal pellets}

The average fecal pellet clearance rates of Acartia tonsa and Temora longicornis females were generally low when compared with average clearance rates for other copepod species in most other comparable laboratory studies (Table 5). One exception is Besiktepe \& Dam (2002), who also found low feeding rates on own pellets in A. tonsa. However, our study reveals that the clearance rate of fecal pellets is influenced by numerous factors and therefore comparison between clearance rates reported in the literature is not straightforward.

The most important factor influencing the clearance rate of fecal pellets by copepods is the size of the pellets: fecal pellet clearance rate decreases with increasing relative size of the fecal pellets. This becomes apparent when plotting the available laboratory observations of clearance rates (Table 5) as a function of relative pellet size (Fig. 6). In Fig. 6, we have expressed pellet size relative to copepod prosome length, and we have normalised clearance rates with copepod length squared because vital rates generally scale with the body weight raised to a power of approximately $2 / 3$. The effect of relative fecal pellet size transcends other sources of variation and is evident both in the presence and absence of alternative food. Correcting for size thus makes all available clearance measurements largely consistent with one another.

Theoretically, the clearance rate of pellets should increase dramatically with size above the critical pellet size for detection since a large sinking pellet should create a greater fluid disturbance and therefore be easier to perceive for the copepod (Kiørboe \& Visser 1999). This, of course, requires that the animal perceiving the pellet also ingests it. However, we found the 
Table 5. Pelagic copepods. Average clearance rates $\left(\mathrm{ml}\right.$ copepod ${ }^{-1} \mathrm{~d}^{-1}$ ) of copepods grazing fecal pellets and mixtures of fecal pellets and algae. All values presented are from laboratory studies with copepods feeding on 1 type of fecal pellet at a time and 1 species of alga or natural plankton. Clearance rates were obtained from direct counts of the fecal pellets. 1: Ayukai (1987); 2: Lampitt et al. (1990); 3: Paffenhöfer \& Van Sant (1985); 4: Paffenhöfer \& Knowles (1979)

\begin{tabular}{|c|c|c|c|c|c|c|}
\hline \multirow[t]{2}{*}{$\begin{array}{l}\text { Copepod } \\
\text { species }\end{array}$} & \multirow[t]{2}{*}{$\begin{array}{c}\text { Fecal pellet } \\
\text { producer }\end{array}$} & \multirow[t]{2}{*}{$\begin{array}{c}\text { Pellets } \\
\text { produced on }\end{array}$} & \multirow[t]{2}{*}{$\begin{array}{l}\text { Fecal pellet } \\
\text { size (ESD) }\end{array}$} & \multicolumn{2}{|c|}{$\begin{array}{l}\text { Max. pellet clearance } \\
\left(\mathrm{ml} \mathrm{copepod}^{-1} \mathrm{~d}^{-1}\right)\end{array}$} & \multirow[t]{2}{*}{ Source } \\
\hline & & & & Only pellets & Pellets + algae & \\
\hline \multirow[t]{4}{*}{$\begin{array}{l}\text { Acartia tonsa } \\
\text { females }\end{array}$} & $\begin{array}{l}\text { A. tonsa } \\
\text { CI to III }\end{array}$ & $\begin{array}{l}\text { Rhodomonas } \\
\text { salina }\end{array}$ & 40 & 9 & $21+T$. weissflogii & This study \\
\hline & Own pellets & $\begin{array}{l}\text { Thalassiosira } \\
\text { weissflogii }\end{array}$ & 70 & & $16+T$. weissflogii & This study \\
\hline & Own pellets & $\begin{array}{l}\text { Dunaliella } \\
\text { tertiolecta }\end{array}$ & 45 & & $5+D$. tertiolecta & This study \\
\hline & $\begin{array}{l}\text { Calanus spp. } \\
\text { CV to CVI }\end{array}$ & $\begin{array}{l}\text { Rhodomonas } \\
\text { salina }\end{array}$ & 130 & 4 & $6+T$. weissflogii & This study \\
\hline $\begin{array}{l}\text { Acartia omorii } \\
\text { females }\end{array}$ & $\begin{array}{l}\text { A. omorii } \\
\text { CI to CIII }\end{array}$ & $\begin{array}{l}\text { Thalassiosira } \\
\text { decipiens }\end{array}$ & 25 & & $50+T$. decipiens & 1 \\
\hline Centropages hamatus $^{\mathrm{a}}$ & Own pellets & Natural plankton & 82 & 10 to 20 & & 2 \\
\hline $\begin{array}{l}\text { Eucalanus pileatus } \\
\text { CV }\end{array}$ & $\begin{array}{l}\text { Paracalanus spp. } \\
\text { CV/females }\end{array}$ & $\begin{array}{l}\text { Isochrysis } \\
\text { galbana }\end{array}$ & 51 & $\begin{array}{l}211 \\
211\end{array}$ & $\begin{array}{c}223+R . \text { alata } \\
287+T . \text { weissflogii }\end{array}$ & $\begin{array}{l}3 \\
3\end{array}$ \\
\hline $\mathrm{CV}+$ females & $\begin{array}{l}\text { E. pileatus } \\
\text { nauplii }\end{array}$ & $\begin{array}{l}\text { Rhizosolenia } \\
\text { alata }\end{array}$ & 47 & & $275+R$. alata & 4 \\
\hline $\begin{array}{l}\text { Temora longicornis } \\
\text { females }\end{array}$ & Own pellets & $\begin{array}{l}\text { Thalassiosira } \\
\text { weissflogii }\end{array}$ & 75 & & $11+T$. weissflogii & This study \\
\hline $\begin{array}{l}\text { Temora stylifera } \\
\text { adults }\end{array}$ & $\begin{array}{l}\text { E. pileatus } \\
\text { nauplii }\end{array}$ & $\begin{array}{l}\text { Rhizosolenia } \\
\text { alata }\end{array}$ & 51 & & $320+R$. alata & 4 \\
\hline
\end{tabular}

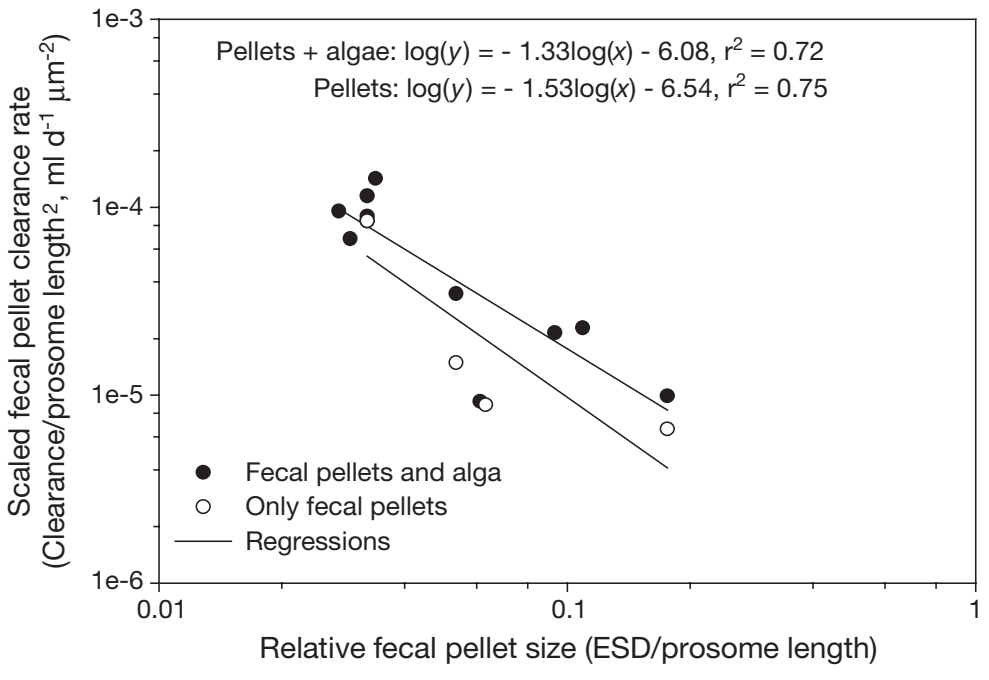

Fig. 6. Copepod fecal pellet clearance rate (normalised by copepod prosome length squared) as a function of relative pellet size (ESD/copepod prosome length) in the absence $(0)$ or presence $(\bullet)$ of alternative food. Clearance rates and pellet sizes were taken from Table 5. Prosome lengths of copepods were: Acartia omorii: $860 \mu \mathrm{m}$ (Ueda 1986), Acartia tonsa: $735 \mu \mathrm{m}$ (Dunaliella tertiolectra) or $778 \mu \mathrm{m}$ (Thalassiosira weissflogii) (this study), Centropages hamatus (adults): $1400 \mu \mathrm{m}$ (Farran 1948), Eucalanus pileatus CV: $1580 \mu \mathrm{m}, \mathrm{CV}$ + females: $1700 \mu \mathrm{m}$ (Dessier 1985), Temora longicornis: $695 \mu \mathrm{m}$ (this study), Temora stylifera: $1500 \mu \mathrm{m}$ (Mori 1937) opposite tendency that pellet clearance decreases with increasing pellet size, presumably because larger pellets become increasingly difficult to handle and are not ingested. In this study, only small fragments were ingested by Acartia tonsa females and mostly during suspension feeding, which may indicate that the ingestion of small pellets or pellet fragments occurs more or less unintentionally along with the alternative food. A prey-size dependent clearance rate in copepods has long been recognized (Frost 1972, Berggreen et al. 1988), and has also previously been demonstrated for copepods feeding on fecal pellets. For example, Acartia clausi females remove naupliar fecal pellets in preference to larger copepodite pellets (Piontkovsky \& Petipa 1975 in Green et al. 1992).

The food source on which the fecal pellets have been produced is also important for the clearance rate of the pellets as it influences the size, compaction (Hansen et al. 1996), and the nutritional value of the 
pellets. In this study, the average fecal pellet equivalent spherical diameter (ESD) of Acartia tonsa pellets produced on Thalassiosira weissflogii is almost double the size of pellets produced on Dunaliella tertiolecta (Table 1). Besiktepe \& Dam (2002) likewise found that pellets produced on diatom diets were larger than flagellate based pellets in A. tonsa. This may be a general phenomenon related to the silicon frustules of diatoms. Fecal pellets produced on flagellates compared to diatoms are more fragile and less dense (Hansen et al. 1996). The compaction of the pellet may therefore influence the degradation of the pellet since fragmentation of fragile pellets may be more severe during rejection causing higher apparent clearance rates, due to underestimation of the pellet concentration during counting. However, the clearance rate of A. tonsa on pellets produced on $D$. tertiolecta was lower than for pellets produced on $T$. weissflogii. $D$. tertiolecta was offered at saturating food concentrations. Thus, the low clearance rate of the smaller pellets produced on $D$. tertiolecta is most likely caused by the poor nutritional value of this algae for copepods (Koski et al. 1998, Klein Breteler et al. 1999) making pellets produced on this alga a less attractive food source.

Different copepod species may adapt differently to feed on fecal pellets and detritus. In this study, it is shown that Acartia tonsa and Temora longicornis clear their own fecal pellets at similar rates when offered in a mixture with Thalassiosira weissflogii. Both species are common in coastal waters and a low clearance of fecal pellets may be an adaptation to optimize the intake of high quality food particles in an estuarine environment where non-living particles usually dominate the particulate matter available to copepods (Paffenhöfer \& Van Sant 1985). Supporting this, Roman (1984) found that only $10 \%$ of a laboratory population of $A$. tonsa survived $7 \mathrm{~d}$ on a detritus diet and that eggs could not be reared to adults on detritus. Other copepod species such as Eucalanus pileatus, Temora stylifera, and Oithona similis may be better adapted to coprophagous feeding since they clear and ingest fecal pellets at high rates (Table 5, Paffenhöfer \& Knowles 1979, Paffenhöfer \& Van Sant 1985, González et al. 1994a). Copepodites of the more oceanic Calanus helgolandicus have been reared to adulthood on a pure diet of fecal pellets in the laboratory (Paffenhöfer \& Knowles 1979) and Acartia omorii has been shown to even prefer fecal pellets over Thalassiosira decipiens when offered in a mixture (Ayukai 1987).

The functional response in fecal pellet clearance and ingestion to pellet concentration was controlled by the presence of Thalassiosira weissflogii and absent when pellets were offered as the sole food source. Centropages hamatus also lacks a functional response when grazing solely fecal pellets (Lampitt et al. 1990), and Eucalanus pileatus similarly has a higher fecal pellet grazing rate in the presence than in the absence of phytoplankton (Table 5, Paffenhöfer \& Van Sant 1985). Paffenhöfer \& Van Sant (1985) concluded that the feeding rate on non-living food particles was a function of the feeding rate on living food particles and that the increased ingestion of pellets in the presence of $T$. weissflogii was attributed to an increased filtration activity similar to what we observe here for Acartia tonsa. Calanus helgolandicus nauplii, however, have been observed to have a very different feeding response to fecal pellets and other food particles (Green et al. 1992). C. helgolandicus nauplii cleared fecal pellets at a higher rate when alternative food (Isochrysis galbana) was limiting than when alternative food was plentiful. C. helgolandicus nauplii therefore seem to perceive fecal pellets as food particles.

The feeding mode engaged by Acartia tonsa females in itself influence the clearance rate of fecal pellets. The females switch from mainly sluggish ambush feeding behaviour when offered fecal pellets alone to suspension feeding when grazing a mixture of Thalassiosira weissflogii and pellets. During suspension feeding the females encounter and reject fecal pellets more often than during ambush feeding especially at high pellet concentrations. Copepods without special adaptation to feeding on fecal pellets should therefore, in general, have higher clearance rates on fecal pellets when engaging suspension feeding than when engaging ambush feeding.

In this study, the fragmentation occurred during the rejection of pellets caught in the feeding current of the animal. Fecal pellets were visibly opened, macerated and even cut in half during rejection. Eucalanus pileatus females have also been observed to inflict damage to fecal pellets during rejection (Paffenhöfer \& Van Sant 1985) and Acartia clausi and Calanus finmarchicus were observed to fragment rather than ingest fecal pellet material (Noji et al. 1991).

\section{Ecological implications}

It has been hypothesised that removal by metazooplankton is the most likely fate of fecal material in the upper layers of the sea (Paffenhöfer \& Knowles 1979, Lampitt et al. 1990, González \& Smetacek 1994, Viitasalo et al. 1999) since bacteria alone can not be responsible for the majority of the remineralisation of freshly egested fecal pellets (Jacobsen \& Azam 1984, Lampitt et al. 1990). Support for this hypothesis is found in the few existing publications, which show that some copepod species do clear fecal pellets at high rates in the laboratory (Table 5). Coprophagy has consequently been used to explain this disappearance of 
fecal pellets. However, the visual observations in this study show that the pellet degradation in Acartia tonsa females is mainly due to coprorhexy and only to a lesser degree coprophagy. Visual observations of the feeding behaviour of copepods grazing fecal pellets have only been performed for $A$. tonsa females in this study and by Paffenhöfer \& Van Sant (1985) for tethered Eucalanus pileatus females. Both studies observed rejection of fecal pellets. Thus, coprorhexy rather than coprophagy may account for the role of some copepods in reducing the vertical flux of fecal pellets, by turning pellets into smaller, slower-sinking fragments, which are more prone to microbial degradation (Noji et al. 1991). Evidence of coprorhexy has been found in the field where fecal pellets were observed to be converted into small, amorphous particles (Knappertsbusch \& Brummer 1995, Suzuki et al. 2003).

The increasing clearance of fecal pellets with decreasing pellet size may also explain the higher vertical flux of fecal pellets observed when large Calanus species as opposed to small copepod species dominate the zooplankton community (González et al. 1994a, Viitasalo et al. 1999, Wassmann et al. 2000). A high ratio of large calanoid to small cyclopoid copepods is generally related to a high vertical flux of fecal pellets and a low ratio to a low flux of pellets (González \& Smetacek 1994, Svensen \& Nejstgaard 2003). This coherence could also be caused by the higher sinking rates of large fecal pellets, which may induce a higher vertical flux of pellets when large copepods dominate the copepod community. However, large pellets have been observed to be degraded at high rates within the water column resulting in low vertical fluxes (González et al. 1994a, Wexels Riser et al. 2002).

Also, the phytoplankton community influence the size and the sinking rate of the fecal pellets. Fecal pellets produced during the diatom dominated spring bloom are larger, sink faster, are more persistent, and are cleared and degraded at lower rates by copepods due to handling difficulty than pellets produced during a flagellate dominated post-bloom situation (Hansen et al. 1996, Feinberg \& Dam 1998, Besiktepe \& Dam 2002, Thor et al. 2003).

Thus, the role of Acartia tonsa and Temora longicornis in degrading fecal pellets is mainly to turn pellets into smaller, slower sinking particles during rejection, which are more easily degraded by other organisms in the sea. A. tonsa and T. longicornis in general have low clearance rates on fecal pellets and only ingest smaller fragments of fecal pellets.

Acknowledgements. We are very grateful to P. Lewy, Danish Institute for Fisheries Research, Dept. of Marine Fisheries for statistical assistance with fitting the logarithmic transformed model in ' $\mathrm{R}$ ' and computing the Likelihood ratios. L.K.P. was supported by the SLIP research school under the Danish Net- work for Fisheries and Aquaculture Research financed by the Danish Ministry for Food, Agriculture, and Fisheries and the Danish Agricultural and Veterinary Research Council, and T.K. by a grant from the Danish Natural Science Research Council (\#21-01-0549).

\section{LITERATURE CITED}

Ayukai T (1987) Rate of filtering of fecal pellets by Acartia omorii (Copepoda; Calanoida). J Oceanogr Soc Jpn 42: 487-489

Ayukai T, Nishizawa S (1986) Defecation rate as a possible measure of ingestion rate of Calanus pacificus pacificus (Copepoda: Calanoida). Bull Plankton Soc Jpn 33(1):3-10

Bathmann UV, Noji TT, Voss M, Peinert R (1987) Copepod fecal pellets: abundance, sedimentation and content at a permanent station in the Norwegian Sea in May/June 1986. Mar Ecol Prog Ser 38:45-51

Berggreen U, Hansen B, Kiørboe T (1988) Food size spectra, ingestion and growth of the copepod Acartia tonsa during development: implications for determination of copepod production. Mar Biol 99:341-352

Besiktepe S, Dam HG (2002) Coupling of ingestion and defecation as a function of diet in the calanoid copepod Acartia tonsa. Mar Ecol Prog Ser 229:151-164

Dessier A (1985) Dynamique et production d'Eucalanus pileatus (Copepoda: Calanoida) à Pointe-Noire (République Populaire du Congo). Océanogr Trop 20(1):3-18

Farran GP (1948) Copepoda Sub-Order: Calanoida, Family: Centropagidae, Genus: Centropages. Fiches d'identification du zooplancton, 11. ICES, Copenhagen

Feinberg LR, Dam HG (1998) Effects of diet on dimensions, density and sinking rates of fecal pellets of the copepod Acartia tonsa. Mar Ecol Prog Ser 175:87-96

Frost BW (1972) Effects of size and concentration of food particles on the feeding behavior of the marine planktonic copepod Calanus pacificus. Limnol Oceanogr 17(6): 805-815

González HE, Smetacek V (1994) The possible role of the cyclopoid copepod Oithona in retarding vertical flux of zooplankton faecal material. Mar Ecol Prog Ser 113: $233-246$

González HE, González SR, Brummer GA (1994a) Short-term sedimentation pattern of zooplankton, faeces and microplankton at a permanent station in the Bjørnafjorden (Norway) during April-May 1992. Mar Ecol Prog Ser 105: 31-45

González HE, Kurbjeweit F, Bathmann UV (1994b) Occurrence of cyclopoid copepods and faecal material in the Halley bay region, Antarctica, during January-February 1991. Polar Biol 14:331-342

Green EP, Harris RP, Duncan A (1992) The production and ingestion of faecal pellets by nauplii of marine calanoid copepods. J Plankton Res 14(12):1631-1643

Guillard RRL (1975) Culture of phytoplankton for feeding marine invertebrates. In: Smith WL, Chanley MH (eds) Culture of marine invertebrate animals. Plenum Press, New York, p 29-60

Hamner WM (1990) Design developments in the planktonkreisel, a plankton aquarium for ships at sea. J Plankton Res 12(2):397-402

Hansen B, Fotel FL, Jensen NJ, Madsen SD (1996) Bacteria associated with a marine planktonic copepod in culture. II. Degradation of fecal pellets produced on a diatom, a nanoflagellate or a dinoflagellate diet. J Plankton Res 18(2):275-288 
Jacobsen TR, Azam F (1984) Role of bacteria in copepod fecal pellet decomposition: colonization, growth rates and mineralization. Bull Mar Sci 35(3):495-502

Jonsson PR, Tiselius P (1990) Feeding behaviour, prey detection and capture efficiency of the copepod Acartia tonsa feeding on planktonic ciliates. Mar Ecol Prog Ser 60:35-44

Jumars PA, Penry DL, Baross JA, Perry MJ, Frost BW (1989) Closing the microbial loop: dissolved carbon pathway to heterotrophic bacteria from incomplete ingestion, digestion and absorption in animals. Deep-Sea Res 36(4): 483-495

Kiørboe T, Visser AW (1999) Predator and prey perception in copepods due to hydromechanical signals. Mar Ecol Prog Ser 179:81-95

Kiørboe T, Saiz E, Viitasalo M (1996) Prey switching behaviour in the planktonic copepod Acartia tonsa. Mar Ecol Prog Ser 143:65-75

Klein Breteler WCM, Schogt N, Baas M, Schouten S, Kraay GW (1999) Trophic upgrading of food quality by protozoans enhancing copepod growth: role of essential lipids. Mar Biol 135:191-198

Knappertsbusch M, Brummer GA (1995) A sediment trap investigation of sinking coccolithophorids in the North Atlantic. Deep-Sea Res I 42(7):1083-1109

Koski M, Klein Breteler WCM, Schogt N (1998) Effect of food quality on rate of growth and development of the pelagic copepod Pseudocalanus elongatus (Copepoda, Calanoida). Mar Ecol Prog Ser 170:169-187

Lampitt RS, Noji TT, Von Bodungen B (1990) What happens to zooplankton faecal pellets? Implications for material flux. Mar Biol 104:15-23

Lane PVZ, Smith SL, Urban JL, Biscaye PE (1994) Carbon flux and recycling associated with zooplanktonic fecal pellets on the shelf of the Middle Atlantic Bight. Deep-Sea Res II 41(2/3):437-457

Mori T (1937) The pelagic copepoda from the neighbouring waters of Japan. Yokendo Co.

Noji TT, Estep KW, MacIntyre F, Norrbin F (1991) Image analysis of faecal material grazed upon by 3 species of copepods: evidence for coprorhexy, coprophagy and coprochaly. J Mar Biol Assoc UK 71:465-480

Paffenhöfer GA, Knowles SC (1979) Ecological implications of fecal pellet size, production and consumption by copepods. J Mar Res 37(1):35-49

Paffenhöfer GA, Strickland JDH (1970) A note on the feeding of Calanus helgolandicus on detritus. Mar Biol 5:97-99

Paffenhöfer GA, Van Sant KB (1985) The feeding response of a marine planktonic copepod to quantity and quality of particles. Mar Ecol Prog Ser 27:55-65

Editorial responsibility: Otto Kinne (Editor-in-Chief), Oldendorf/Luhe, Germany
Piontkovsky SA, Petipa TS (1975) Selectivity in the feeding of Acartia clausi. Biol Morya 33:3-11

Roman MR (1984) Utilization of detritus by the copepod, Acartia tonsa. Limnol Oceanogr 29(5):949-959

Smetacek VS (1980) Zooplankton standing stock, copepod faecal pellets and particulate detritus in Kiel Bright. Estuar Coast Mar Sci 11:477-490

Støttrup JG, Richardson K, Kirkegaard E, Pihl NJ (1986) The cultivation of Acartia tonsa Dana for use as a live food source for marine fish larvae. Aquaculture 52:87-96

Suzuki H, Sasaki H, Fukuchi M (2003) Loss processes of sinking fecal pellets of zooplankton in the mesopelagic layers of the Antarctic Marginal Ice Zone. J Oceanogr 59:809-818

Svensen C, Kiørboe T (2000) Remote prey detection in Oithona similis: hydromechanical versus chemical cues. J Plankton Res 22(6):1155-1166

Svensen C, Nejstgaard JC (2003) Is sedimentation of copepod faecal pellets determined by cyclopoids? Evidence from enclosed ecosystems. J Plankton Res 25(8):917-926

Thor P, Dam HG, Rogers DR (2003) Fate of organic carbon released from decomposing copepod fecal pellets in relation to bacterial production and ectoenzymatic activity. Aquat Microb Ecol 33:279-288

Turner JT (2002) Zooplankton fecal pellets, marine snow and sinking phytoplankton blooms. Aquat Microb Ecol 27: 57-102

Ueda H (1986) Taxonomic reexamination and geographical distribution of copepods known as Acartia clausi in Japanese coastal and inlet waters. J Oceanogr Soc Jpn 42: $134-138$

Urban-Rich J (1999) Release of dissolved organic carbon from copepod fecal pellets in the Greenland Sea. J Exp Mar Biol Ecol 232:107-124

Urban-Rich J, Nordby E, Andreassen IJ, Wassmann P (1999) Contribution by mesozooplankton fecal pellets to the carbon flux on Nordvestbanken, North Norwegian Shelf in 1994. Sarsia 84:253-264

Viitasalo M, Rosenberg M, Heiskanen A, Koski M (1999) Sedimentation of copepod fecal material in the coastal northern Baltic Sea: Where did all the pellets go? Limnol Oceanogr 44(6):1388-1399

Wassmann P, Ypma JE, Tselepides A (2000) Vertical flux of faecal pellets and microplankton on the shelf of the oligotrophic Cretan Sea (NE Mediterranean Sea). Prog Oceanogr 46:241-258

Wexels Riser C, Wassmann P, Olli K, Pasternak A, Arashkevich E (2002) Seasonal variation in production, retention and export of zooplankton faecal pellets in the marginal ice zone and central Barents Sea. J Mar Syst 38:175-188

Submitted: November 22, 2004; Accepted: April 12, 2005 Proofs received from author(s): August 4, 2005 